\title{
SUR L'EMPLOI DES IODOPHORES EN PISCICULTURE
}

\author{
établie par M. J.-P. GERARD, Docteur Vétérinaire \\ Laboratoire d'Ichtyopathologie de I'INRA \\ 78850 THIVERVAL-GRIGNON
}

\section{Présentation :}

Les iodophores se présentent sous forme d'un liquide de couleur brune dont le titre en iode actif est variable selon le fabricant. Deux produits sont actuellement commercialisés en France : la Wescodyne et le Roméiod*.

- la Wescodyne titre $1,6 \%$ d'iode actif.

- le Roméiod titre 0,5\% d'iode actif.

Il importe donc de bien lire l'étiquette avant l'emploi pour éviter tout accident.

\section{Indications :}

Les iodophores sont des désinfectants très actifs et à ce titre ils peuvent être employés pour désinfecter le matériel de la pisciculture (épuisettes, auges d'alevinage, bassins) et les mains et bottes des opérateurs. les œufs.

Toutefois, étant donné leur prix ils seront surtout utilisés pour désinfecter

Les œufs de poissons sont, en effet, les vecteurs de choix des agents de la plupart des maladies contagieuses en assurant leur passage de l'adulte reproducteur, porteur de germes, aux alevins, ceci en dehors de toute contamination par l'eau.

Parmi les agents pathogènes ainsi transmis, il apparait que seul le virus de la Nécrose Pancréatique Infectieuse des salmonidés est à la fois à l'intérieur et à la surface de l'œuf, tous les autres agents sont à sa surface. La désinfection des cufs est donc un moyen de choix pour couper la transmission des maladies contagieuses à l'exception de la Nécrose Pancréatique Infectieuse dont le virus situé à l'intérieur de l'œuf ne peut être atteint. La désinfection évitera la transmission, par l'œuf, des maladies suivantes : Septicémie Hémorragique Virale, Nécrose Hématopoiëtique Infectieuse, Furonculose et autres Aeromonoses, Costiose. En revanche, les spores de champignons se sont montrées résistantes.

* Laboratoire Romeil-Orleans. 


\section{Toxicité :}

Ces produits, aux doses conseillées, ne sont pas toxiques pour les œufs, et sont très actifs contre les virus et les bactéries.

Par contre, ils sont très toxiques pour les poissons, c'est pourquoi la solution thérapeutique ne sera jamais rejetee après usage dans les bassins. Pour éviter des accidents, elle sera neutralisée après usage par une solution appelée " lopháge "*, utilisée à la même concentration que l'iodophore.

\section{Posologie :}

\section{1 - Pour la désinfection du matériel.}

Pour désinfecter, la dose sera de $250 \mathrm{ppm}$ (1), soit :

- avec le Roméiod à $0,5 \%$ d'iode libre : $50 \mathrm{ml}$ par litre ;

- avec la Wescodyne à 1,6\% d'iode libre : $20 \mathrm{ml}$ par litre'

\section{II - Pour la désinfection des œufs.}

\section{La dose que nous prescrivons est de 50 ppm (1)}

La solution thérapeutique sera obtenue en mélangeant :

soit $10 \mathrm{ml}$ ( 2 cuillerées à café) de Roméiod $0,5 \%$ par litre d'eau,

soit $10 \mathrm{ml}$ (2 cuillerées à café) de Wescodyne 1,6\% par 3 litres d'eau.

\section{Mode d'emploi :}

II est nécessaire de vérifier à l'aide d'un papier indicateur de $\mathrm{pH}$ le $\mathrm{pH}$ de cette solution qui doit être inférieur à 8 . On peut employer le bicarbonate de soude pour le corriger dans les eaux acides.

\section{I - Pour la désinfection.}

Pour la désinfection, le produit peut être employé soit en pulvérisation, soit par brossage. Les objets à désinfecter peuvent être également immergés dans la solution. Cette dernière doit être employée dès sa préparation. En solution concentrée, les iodophores sont stables et peuvent se conserver plusieurs mois au frais et à l'obscurité. En solution étendue nous déconseillons l'emploi d'une solution préparée depuis plus de 12 heures.

\section{II - Pour le traitement des œufs.}

Les œufs peuvent être traités :

- soit aussitôt la fécondation,

- soit lorsqu'ils sont embryonnés au stade de "l'œil", c'est-à-dire quand les yeux apparaissent très nettement sous forme de deux gros points noirs.

Les œufs achetés seront donc traités dès leur arrivée, car c'est à ce stade qu'ils sont commercialisés. suivantes :

Pour ces derniers, nous vous conseillons d'effectuer les opérations

* Laboratoire Romeil-Orléans.

(1) ppm : partie par million, soit un gramme par mètre cube ou un milligramme par litre. 
- Déballer les œufs dans un local situé hors du laboratoire, mais dont la température ambiante sera identique à celle du local où s'achèvera l'incubation. Se méfier du gel ou du soleil.

- Arrosez-les d'eau pour les amener progressivement à la température où ils seront incubés. Ne pas leur faire subir une variation de température supérieure à deux degrés par heure.

Ne pas rejeter l'eau utilisée pour la mise en température dans les bassins de la pisciculture, car les œuf́s à traiter doivent être considérés comme contaminès.

- Placer ensuite ces œufs sur les claies d'incubation, puis les baigner dans la solution désinfectante. Cette solution sera préparée avec l'eau utilisée pour les arroser afin d'éviter tout choc thermique. Prévoir 50 à 60 litres de solution pour traiter 100000 œufs. Trois ou quatre lots d'œufs pourront être traités avec la même solution si elle est utilisée dans la journée où elle a été préparée.

\section{Durée et périodicité du traitement.}

\section{- Pour la désinfection.}

Les iodophores aux doses indiquées détruisent presque instantanément les virus et les bactéries. Toutéfois, pour obtenir une marge de sécurité importante, il est souhaitable de laisser agir 10 minutes environ le désinfectant. Rincer plusieurs fois les objets désinfectés avant de les mettre en service s'ils sont destinés à la manipulation des poissons, car. il ne faut pas oublier que le produit est toxique.

II - Pour le traitement des œufs.

10 minutes et uno seule fois.

Après la balnëation, rincer les œufs au, moins trois fois pour éliminer toutes traces d'iodophore. 